\title{
INVENTORY MANAGEMENT: RAW MATERIALS FOR SMALL ENTERPRISE
}

\author{
Dewi Nusraningrum, and Truong Trong Nhan \\ Universitas Mercu Buana Jakarta, Indonesia \\ Dong Nai University of Technology, Vietnam.
}

\begin{abstract}
This community service is an activity related to community economic empowerment through understanding the supplies of raw materials. Problems that arise on the supply of raw materials requires capital and affect submission to the customer. In order to support the efforts of the economic empowerment of the community outreach and training about the usefulness of the inventory of raw materials through the citizens who live in the village of partners will help citizens find out how partners do materials inventory management to improve the welfare of society. For that these activities would provide mentoring and training skills inventory management of raw materials, in order to be later able to apply them in the activities of partners to manage its business. External expected can be realized from this activity are: (1) the development of raw material inventory management knowledge on the citizens of the Small Enterprise. (2) the formation of social groups care inventory management on Small Enterprise.
\end{abstract}

Keywords: Community, Inventory Management, Raw Materials, Welfare

\section{Introduction}

Inventory management has an impact on all business functions, particularly the operations, marketing and finance. The inventory provides services to customers who are very vital to marketing. Finance related to financial circumstances across the entire organization, including funds allocated for supplies. And operations requires preparation to ensure smooth and efficient production. However, there is a supply of goals that conflict within the company. Financial functions usually liked the low inventory levels to conserve capital, marketing a high inventory levels of liking to increase sales, while some operations requires high inventory for the long-term production and level of use of the workers. Inventory management must balance this objective contradictions and manage inventory levels in the interest of what's best for the company as a whole. The effectiveness of production can bring about the possibility of a decrease in costs - the cost of production, which in the end will make the industry set a selling price that can compete against products and the ability of the industry to meet the customer's exact booking on the time (Ahyari, 1992).

Traditional stalls in West Jakarta, many of which are suspended. The team's best friend Businesses people (subSaharan Africa) from the Office of small and Medium Businesses and Cooperative Trade West Jakarta has a record of traditional business online and provide assistance in that consignment. The help given to the traditional stalls every neighboring one stall that belonged to the natives, not proprietary leases still active and need help. Currently, the number of Pillars in the region of the neighboring West Jakarta as much 6.435 neighboring community (http://jakarta.tribunnews.com/2018/08/13/).

\section{Problems}

The community has come to know the inventory management in a simple, through small business activities performed daily. The new society was limited to know and some try to do inventory management. How to implement inventory management properly so that the work done getting the maximum benefit? Based on the results of observation and interview in the village of South Meruya Subdistrict Kembangan that community interested or wishes get advanced training and coaching on inventory management of raw materials for self development and pengingkatan income for his efforts. How to inventory management of raw material that is efficient and effective to increase profits? 


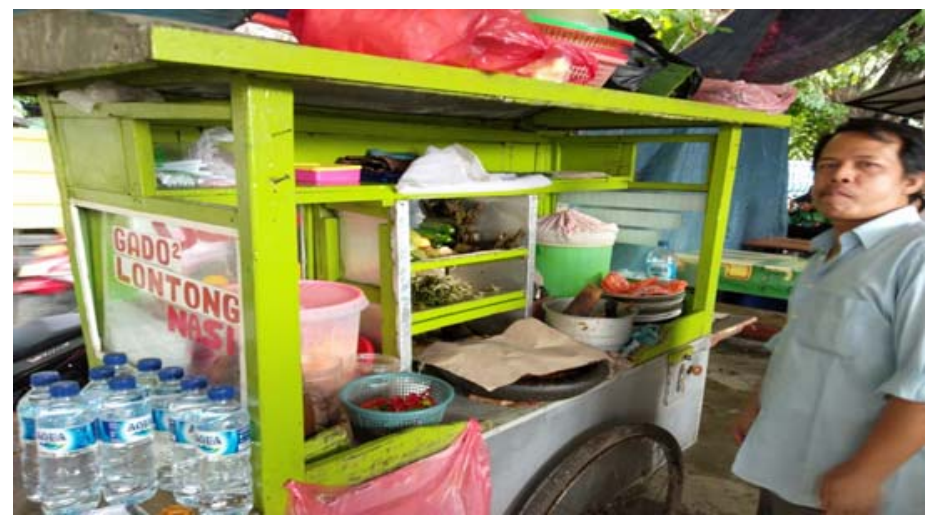

Figure 1. Indonesian Salad- Street Seller

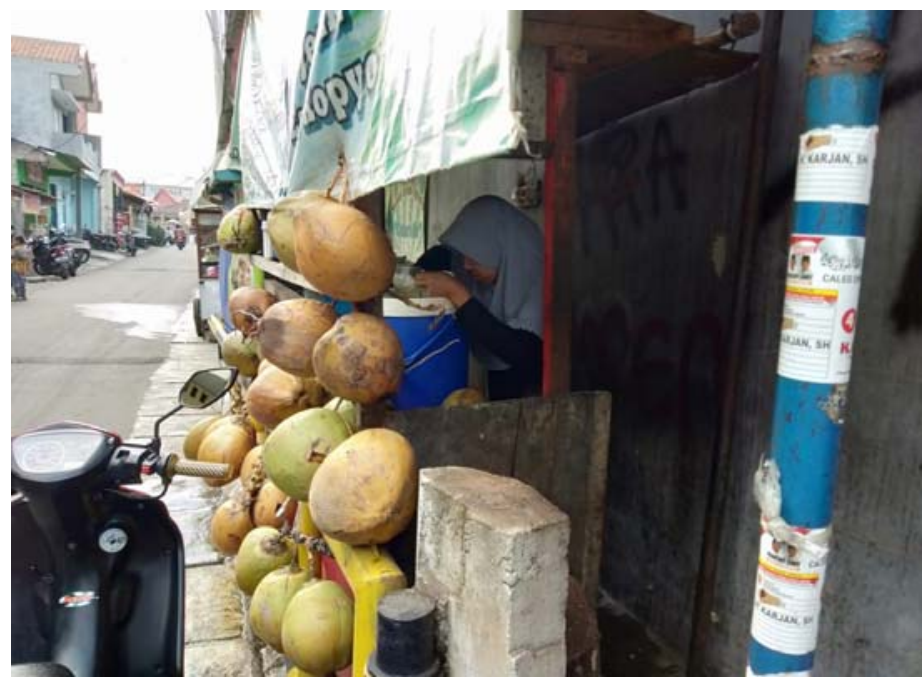

Figure 2. Young Coconut Drink-Street Seller

There are various problems in inventory management decisions:

1. what Items should be kept as stock?

2. How much to order?

3. When an order should be placed?

4. What type of inventory control system used?

\section{Solution and Target}

Based on the perceived problems of society, especially the sub districts of South Meruya, West Jakarta, then an alternative solution that offered training for inventory management of raw materials in an effort to boost sales provide additional impact on family income conducted by: providing knowledge and capability gap solutions, popularized the inventory management of raw materials. Provide solutions and ways of coping strategies inventory of raw materials. Give the solution how to choose suppliers by means of effective and efficient.

The capacity of the present potential for producing, while inventory is the product at some point in the process of conversion and distribution. The preparation acts as a buffer between the difference of level between supply and demand. The main purpose of the inventory is to separate the different stages of the operation. Inventories raw materials separate the factory with suppliers. Inventory of the goods in the process of separating the various stages of manufacturing with one another and manufacturing finished goods inventory is separate from customers. In the absence of supplies, the employers will be faced with the risk that at some time the company can not meet the wishes of its customers (Christianti, 2011).

Why do we manage the inventory?

1. To Protect Against Uncertainty.

In the system of preparation there is uncertainty on supply, demand and the waiting time. The stock of security held in inventory to protect against uncertainty. If consumer demand is known, then it would be "feasible" to 
produce the same amount with consumption, although this method is not always economical. In this case, it is not necessary the preparation of finished goods, but each of the changes that occur in the request should be forwarded to the operating system so that it can be sustained service to the customer. Stock of raw materials for safeguards menarnpung uncertainty the surrender by the supplier. Generally, the supplies are made to absorb uncertainty called safety stock. But if the source of this varieties can be reduced, then the safety stock and supplies can be similarly reduced.

\section{Open the opportunity of production and an economical purchase}

It is often more economical to manufacture materials in large numbers. Within this, a number of items can be produced for a short period and then not again until the number was produced almost close up. This allows the deployment cost of manufacture (set-up cost) of production machines for a large number of items. The same situation can be distinguished on the purchase of raw materials. The advantage of booking fees, quantity, and cost of transportation, often become economical to hold purchases in large quantities, although most of that amount must be saved as inventory for later usage. lnventori as a result of the purchase or production of large amounts of material are often called cycle inventory because the number was produced or purchased over the cycle. But nowadays is going to suppress the trend of the time and cost of making drastically with the road change the product or process. This will result in a number of smaller and lower inventories.

3. To close the changes in supply and demand are estimated.

There are several kinds of situations where changes in supply and demand can be estimated in advance. One case is where the price or availability of raw materials are expected to be changed. Companies often stockpiling steel before the occurrence of strikes in the steel industry. Other sources estimate is a planned market promotion where a large amount of finished goods may precede the sale. Finally, companies in the business of seasonal often anticipate a request to launch a job. For example an airconditioners manufacturer may select a level of product that is almost uniform, although most of its products are sold in the summer. Any inventory that is stored on the basis of estimates of supply and demand is called anticipation inventory.

\section{To face a state of inventory transit.}

lnventory transit consists of materials that are in transit from one point to another. This decision is influenced by the inventory factory and the selection of a tool carrier. Technically, the transfer of supplies between the stages of production, though in one factory, may also be classified as inventory in transit. Sometimes called transit supplies pipeline inventory because it is in the distribution pipeline.

\section{Discussion}

The small size of company usually has difficulties in negotiation with suppliers. They must seek out those suppliers who are willing to offer optimal discounts, terms, and conditions. So, they have to develop better relationship among supplier to ensure optimal use of scarce resources. Entrepreneurs must optimize their resources to engender profitability and stability by selling sufficient quantities of desirable products at acceptable prices (Freeman, 2008).

Companies can only organize supplies in large amounts, but nevertheless a great inventory does not always benefit the company. Some of the losses in connection with the holding of inventory in large numbers include: 1) storage costs are becoming a big company will be dependent. 2) the company shall prepare a fund large enough to hold the purchase of materials. 3) high cost save and invest in inventory will result in reduced funds for financing and investment in other areas.

4) Company took away the possibility of a sizable risk of damage due to chemical changes in inventories or other reasons. 5) if there is a decline in the price of raw materials, the company will suffer considerable losses anyway. On the other hand, when the company organized its inventory in the amount is relatively small, then some of the weaknesses of these policies include: 6) of the possibility of running out of material because supplies ran out prematurely. 7) due to often run out of material, then the production process becomes not smooth. 8) Preparation that is too small will increase the frequency of purchases, so the cost of the message will also be increased in line with an increase in the frequency of purchase.

To avoid conducting the inventory that is too big or too small, here are some considerations that need to be taken care of by the company in preparation: 1) How the magnitude of the number of units of the material supplies 
held company. 2) when and how the number of units of the material will be purchased by the company. 3) When the company in question will make the purchase again.

There are several kinds of factors that affect the supply of raw materials. As for some of these factors are as follows: 1) Estimates of usage of raw materials. the price of raw materials 2) 3) 4) preparation Fee Policy for purchases 5) Discharging material 6) waiting time 7) Model of purchasing materials 8) seat 9) Inventory repurchase.

\section{Methods}

Raw material inventory management training and improve profits South Meruya Kelurahan, West Jakarta is expected to perform, the participants were able to implement training in disseminating the material, creating a management strategy supplies of raw materials. These activities are conducted to help as well, increasing the income of the community in having a business to thrive and compete. Inventory management training to answer the multitude of problems that the community is capable of producing, but difficulty in inventory management of raw materials. Therefore these activities are indispensable for training also increases the confidence of the community in the starting inventory management of raw material correctly.

a. Lecture and discussion. This method was chosen to convey important concepts to understand and mastered by participants. The use of this method with the consideration that methods of lecture combined with audio and video can provide a relatively much material in solid, fast and easy. The material provided in the form of knowledge of inventory management. This activity also chose a supplier, recognize consumers, build partnerships in the ease and accelerate the increase in the market.

b. Monitoring and evaluation. This method was chosen to monitor the extent to which the development and the ability of participants to implement inventory management.

\section{Conclusion}

By building awareness and creating community and raising public inventory management more broadly and increase revenue through: training that gives the understanding and awareness of the need for inventory management of raw materials for increase revenue and provide practical material on inventory management of raw materials. The activities of the community is beneficial to related parties expected, namely: protecting against uncertainty, opening the opportunity of production and purchase of an economical, to cover changes in supply and demand It is estimated, increase the ability of seeing the needs and tastes of consumers.

\section{Recommendation}

Items should be kept as stock, with regard to whether the goods that will be created to inventory (made to stock) or created on the basis of orders (made to order). It also deals with the issue as to whether the goods are forwarded in stock or discontinued. Many inventory includes many items that are obsolete or "insurance items" that his goods are very small. Whether these items will remain stored, saved, removed from the bookkeeping, or added?

Order quantity in regard to the number of ordered when an order is placed is known.

Timing of orders with regard to the time of booking when should be placed/done? The answer to both these questions provide a rules decision that determines when to order and how much to order. To ensure that the correct quantities have been ordered in a timely manner required an inventory control system the system should organize the records accurate, spur bookings when needed, and oversees the flow of incoming materials and out of inventory.

Type of inventory control system used is to match the type of speed or manual systems the right to the problem inventory.

\section{References}

Ahyari. 1992. Manajemen Produksi: Pengendalian Produksi. Yogyakarta. Fakultas Ekonomi UGM.

Ardiansyah, Novian. 2018. Majukan Usaha Kecil Sudin KUKMP JakBar Mendata Secara Online Warung Tradisional di Wilayahnya. Retrieved from http://jakarta.tribunnews.com/2018/08/13/ .

Christianti J, Meliana. Wijaya, Lukas. 2011. Aplikasi Pembelian, Penjualan Obat dan Laporan Keuangan Dengan Menerapkan Manajemen Persediaan. Jurnal Sistem Informasi, Vol 6, No 2. pp. 127 - 141.

Freeman, Ina. 2008. Inventory Planning In Small Business. Journal of Business Case Studies - February 2008 Volume 4, Number 2. Pp.95. 